\title{
POLITIK HUKUM PEMBENTUKAN UNDANG-UNDANG LARANGAN PRAKTEK MONOPOLI DAN PERSAINGAN USAHA TIDAK SEHAT
}

\author{
Wafiya \\ Fakultas Hukum Universitas Bengkulu \\ Email : fiya_ismail@yahoo.com
}

\begin{abstract}
This research aims to outline the policy choice of law in forming the Law on prohibition of monopoly and business competition. Based on the normative approach and by using secondary data, it can be concluded that prior to Act Number 5 of 1999 established, practices of monopoly and business competition are not regulated within the law, after the birth of that Law, business activity is prohibited if it proves detrimental to other businesses, consumers, society and the State. Businessperson that practicing monopoly and unfair business competition among another businessperson obviously threatened by administrative and criminal sanctions. Choice of law is made to anticipate the free market in the era of economic globalization in order to realize the prosperity and welfare of the people as mandated by the 1945 Constitution. Law enforcement of business competition in Indonesia submitted to the supervisor commission of business competition (KPPU), in addition to the involvement of police officers, prosecutors, and courts. Enforcement of competition law violations must be made in advance by the Commission.
\end{abstract}

Keywords: Legal Politic, Prohibition of Monopoly and Unfair Business Competition.

abstrak
Penelitian ini bertujuan untuk menguraikan pilihan kebijakan hukum
dalam pembentukan undang-undang larangan monopoli dan persaingan
usaha. Berdasarkan pendekatan normatif dengan menggunakan data
sekunder dapat disimpulkan bahwa sebelum Undang-Undang No. 5 Tahun
1999 dibentuk praktek-praktek monopoli maupuan persaingan tidak diatur
dalam koridor hukum, sesudah lahirnya undang-undang tersebut kegiatan
bisnis dilarang jika terbukti merugikan pelaku usaha lain, konsumen,
masyarakat, maupun negara. Pelaku bisnis yang mempraktekan monopoli
dan persaingan usaha tidak sehat di antara para pelaku usaha diancam
sanksi administratif dan sanksi pidana. Pilihan hukum dilakukan untuk
mengantisipasi pasar bebas pada era globalisasi ekonomi guna mewujudkan
kemakmuran dan kesejahteraan rakyat sebagaimana diamanatkan UUD 1945 . 
Penegakan hukum persaingan usaha di Indonesia diserahkan kepada Komisi Pengawas Persaingan Usaha (KPPU), selain keterlibatan aparat Kepolisian, Kejaksaan, dan Pengadilan. Penegakan pelanggaran hukum persaingan harus dilakukan terlebih dahulu melalui KPPU.

\section{Kata kunci : Politik hukum, larangan Monopoli dan Persaingan Usaha} Tidak Sehat

\section{A. Pendahuluan}

Suatu pasar di mana tidak terdapat persaingan disebut sebagai "monopoli". Ada beberapa asumsi yang menjadi dasar untuk menentukan adanya monopoli. ${ }^{1}$ Pertama, apabila pelaku usaha mempunyai pengaruh untuk menentukan harga. Kedua, pelaku usaha tidak merasa perlu untuk menyesuaikan diri terhadap pesaing dan terakhir, adanya "entry barrier" bagi pelaku usaha yang ingin masuk dalam pasar yang sudah dimonopoli oleh pelaku usaha. Berdasarkan asumsi-asumsi tersebut, persaingan yang tidak sehat akan mematikan persaingan itu sendiri dan pada gilirannya akan memunculkan monopoli.

Di beberapa negara, hukum persaingan dikenal dengan istilah, "Antitrust Law" atau Anti Monopoli. Di Indonesia istilah yang sering digunakan adalah hukum persaingan atau anti monopoli. Di Indonesia,hukum anti monopoli diatur dalam Undang-Undang Nomor 5 Tahun 1999 tentang Larangan Praktek Monopoli Dan Persaingan Usaha Tidak Sehat. Undangundang ini merupakan pengaturan secara khusus dan komprehensip yang berkaitan dengan persaingan antar pelaku usaha.

Sejarah pertumbuhan perekonomian Indonesia menunjukan bahwa iklim bersaing di Indonesia belum terjadi sebagaimana yang diharapkan, di mana Indonesia telah membangun perekonomiannya tanpa memberikan perhatian yang memadai untuk terciptanya sebuah struktur pasar persaingan. Khususnya pada masa Orde Baru di mana pada waktu itu terjadi kemandekan sistem persaingan dalam dunia usaha, akibat corak kekuasaan Orde Baru yang sangat mementingkan kelompok dan kroni-kroninya agar mendapatkan keuntungan sistem pasar yang monopolistik. Para ahli ekonomi mengatakan bahwa monopoli terjadi bilamana output seluruh industri diproduksi dan dijual oleh satu perusahaan, yang dinamakan monopolis atau perusahaan monopoli. ${ }^{2}$

Kebijakan ekonomi pemerintah Indonesia sejak rezim Soeharto yang dinyatakan dalam GBHN telah mengamanatkan adanya demokrasi ekonomi

\footnotetext{
${ }^{1}$ Michael-Kantz dan Harveey S Rosen, “Microeconomic”, (USA : Richard D Irwin Inc, 1994), hlm. 432-433.

${ }^{2}$ Ibid, hlm. 33 .
} 
tanpa disertai perbuatan curang. Tetapi fakta dilapangan terjadi sebaliknya di mana pemerintah memberikan hak istimewa kepada segelintir pengusaha. Hal ini menimbulkan pemusatan kekuatan ekonomi, terdistorsinya persaingan, dan hilangnya efisiensi. Pemberian hak istimewa yaitu hak monopoli tersebut terlihat pada beberapa industri. Sebagai contoh adalah monopoli cengkeh oleh BPPC (Badan Penyangga Perdangangan Cengkeh) selama 1991-1998. ${ }^{3}$ Campur tangan pemerintah ternyata mengakibatkan terdistorsinya proses persaingan sehingga konsumen menderita karena harga cengkeh yang tinggi, dan petani pun turut mengalami kerugian karena harga cengkeh turun sehingga mengurangi pasokan kepada industri rokok kretek. Hal serupa juga terjadi pada industri kaca lembaran di mana sampai dengan pertengahan 1980 industri kaca lembaran Indonesia diberikan hak monopoli yaitu kepada Asahimas Flat Glass yang merupakan perusahaan patungan Asahi Flat Glass dari Jepang dengan perusahaan lokal yaitu Rodamas Group. ${ }^{4}$

Kasus lain adalah industri pulp dan kertas di mana terjadi tindakan antipersaingan dan campur tangan pemerintah yang telah menimbulkan akumulasi kekuatan pasar dan pemanfaatan kekuatan pasar oleh beberapa pihak. Hal ini tentu saja menimbulkan konsentrasi pasar untuk kertas industri yang semula 37\% menjadi 90\% antara 1985 dan 1995, sedangkan rasio konsentrasi untuk pulp, yaitu bahan baku utama kertas industri selalu berada di atas $90 \%$. Adanya konsentrasi pasar mengakibatkan pemusatan kekuatan ekonomi, ${ }^{5}$ yang berujung pada pemusatan kekuasaan. ${ }^{6}$ Pengusaha juga diberikan hak eksklusif atas pemasaran cengkeh, produksi terigu, dan kedelai. Intervensi pemerintah yang seharusnya diperlukan agar tidak terjadi tindakan anti persaingan, sebaliknya memberikan ruang serta regulasi yang mendukung perilaku para pemburu rente.

Tindakan-tindakan semacam itu dilakukan oleh pemerintah Orde Baru telah menjauhkan Indonesia dari suatu sistem pasar persaingan dan menjadikan Indonesia menghalalkan sistem monopoli pada sektorsektor usaha yang seharusnya lebih layak untuk di persaingkan.

Monopoli dilarang karena mengandung beberapa efek negatif yang merugikan antara lain ;

\footnotetext{
${ }^{3}$ Colleen Loughlin, et al., "Laporan Kebijakan Persaingan Indonesia," ELIPS, Kerja sama antara USAID dengan Pemerintah Indonesia, November 1999, hlm. 26.

${ }^{4}$ Ibid, hlm, 27.

${ }^{5}$ Konsentrasi pasar yang tinggi bukan faktor utama yang menyebabkan timbulnya tindakan antipersaingan. Akan tetapi konsentrasi yang tinggi akan memudahkan perusahaanperusahaan untuk melakukan kolusi dan memanfaatkan kekuatan pasar demi keuntungan mereka. Ibid.

${ }^{6}$ Colleen Loughlin, et al., Op. Cit, hlm. 26.
} 
1. terjadi peningkatan harga suatu produk sebagai akibat tidak adanya kompetisi dan persaingan yang bebas;

2. adanya keuntungan di atas kewajaran yang normal;

3. terjadi eksploitasi terhadap konsumen karena tidak adanya hak pilih konsumen atas produk;

4. terjadi ketidakekonomisan dan ketidakefisienan yang akan dibebankan kepada konsumen;

5. adanya entry barrier di mana perusahaan lain tidak dapat masuk ke dalam bidang usaha perusahaan monopoli; dan

6. pendapatan menjadi tidak merata karena sumber dana dan modal akan tersedot ke dalam perusahaan monopoli.

Hukum persaingan diciptakan dalam rangka mendukung terbentuknya sistem ekonomi pasar, agar persaingan antar pelaku usaha dapat tetap hidup dan berlangsung secara sehat, sehingga konsumen dapat terlindungi dari ajang eksploitasi bisnis.

Meskipun persaingan usaha sebenarnya merupakan urusan antar pelaku usaha, di mana pemerintah tidak perlu ikut campur, namun untuk dapat terciptanya aturan main dalam persaingan usaha, maka pemerintah perlu ikut campur tangan untuk melindungi konsumen. Karena bila hal ini tidak dilakukan maka tidak menutup kemungkinan akan terjadi persekongkolan (kolusi) antar pelaku bisnis yang akan menjadikan inefisiensi ekonomi, yang pada akhirnya konsumenlah yang akan menanggung beban yaitu membeli barang atau jasa dengan harga dan kualitas yang kurang memadai.

Dalam dunia bisnis selalu terjadi tarik menarik antara pendapat yang cenderung menyukai sistem pasar bebas dengan pasar yang diatur oleh pemerintah. Akhirnya digunakan jalan tengah yaitu prinsip kebebasan pasar yang diatur oleh pemerintah, di mana persaingan yang terjadi antar pelaku bisnis menimbulkan persaingan yang sehat dengan cara meningkatkan efisiensi dan produktifitas serta penemuan-penemuan yang baru atas barang maupun jasa. Sebaliknya, persaingan tidak sehat akan dapat merusak perekonomian negara dan akan merugikan masyarakat secara luas.

Ekonomi abad 21 yang ditandai dengan globalisasi ekonomi merupakan proses kegiatan ekonomi dan perdagangan di mana negaranegara dari seluruh dunia menjadi satu kekuatan pasar yang semakin terintegrasi dengan tanpa rintangan batas teritorial negara. Globalisasi menuntut adanya efisiensi dan daya saing dalam dunia usaha. Globalisasi menuntut persaingan bebas yang menganut konsep dekonsentrasi. Mau tidak mau perusahaan-perusahaan lokal harus berdaya saing internasional. Daya saing ini bukan hanya menyangkut kemampuan bersaing memasok produk 
ke pasar internasional tetapi juga di dalam pasar domestik untuk menghadapi pesaing dari luar negeri. ${ }^{7}$

Oleh karena itu, diperlukan perangkat hukum yang dapat mengakses persaingan yang sehat dan mencegah terjadinya persaingan tidak sehat. Perangkat hukum tersebut dapat menjadi sarana bagi pencapaian demokrasi ekonomi di Indonesia. Dan dapat memberikan peluang usaha yang sama bagi semua pelaku bisnis untuk berpartisipasi dalam proses produksi barang maupun jasa dalam iklim usaha yang sehat, efektif dan efisien, serta dapat mendorong adanya pertumbuhan ekonomi pasar yang kondusif.

Dalam perkembangan sistem ekonomi Indonesia, persaingan usaha menjadi salah satu instrumen ekonomi sejak saat reformasi digulirkan. Hal ini ditunjukan melalui terbitnya Undang-Undang Nomor 5 Tahun 1999 tentang Larangan Praktek Monopoli dan Persaingan Usaha Tidak Sehat. Undang-undang ini merupakan tonggak bagi diakuinya persaingan usaha yang sehat sebagai pilar ekonomi dalam sistem ekonomi di Indonesia berdasarkan Pancasila dan Undang Undang Dasar 1945. Kelahiran UndangUndang Nomor 5 Tahun 1999 juga merupakan koreksi terhadap perkembangan ekonomi yang memprihatinkan, yang terbukti tidak tahan terhadap guncangan/krisis pada tahun 1997. Krisis menunjukan bahwa fondasi ekonomi Indonesia sangat lemah. Bahkan banyak pendapat yang mengatakan bahwa ekonomi Indonesia dibangun secara menyimpang dari nilai yang terkandung dalam Pancasila dan Undang-Undang Dasar 1945.

Secara umum analisis dengan menggunakan pendekatan Politik Hukum sangat memungkinkan dalam implementasi Undang-Undang Nomor 5 Tahun 1999, sehingga telah dapat digunakan untuk menjerat berbagai perilaku pelaku usaha yang merugikan masyarakat. Dalam rangka memberikan pemahaman Politik Hukum mengenai Undang-Undang Nomor 5 Tahun 1999, perlu kiranya pengkajian politik hukum dalam pembentukan Undang-Undang Nomor 5 Tahun 1999 yang dapat membawa dimensi baru dalam disiplin ilmu hukum ekonomi di Indonesia. Permasalahannya kemudian adalah bagaimanakah politik hukum pembentukan UndangUndang Nomor 5 Tahun 1999 tentang larangan Praktek Monopoli dan Persaingan Usaha Tidak Sehat?

\section{B. Pembahasan}

\section{Pengertian Politik Hukum dan Persaingan Usaha}

Menurut Sunaryati Hartono, politik hukum sebagai alat (tool) atau sarana dan langkah yang digunakan oleh pemerintah untuk menciptakan

7 Didin S. Damanhuri, SDM Indonesia dalam Persaingan Global, dalam http://www.sinarharapan.co.id/berita/0306/13/opi01.html, terakhir akses Juni 2014. 
sistem hukum nasional yang dikehendaki dan dengan sistem hukum itu akan diwujudkan cita-cita bangsa Indonesia. ${ }^{8}$

Teuku Mohammad Radhie ialah sebagai suatu pernyataan kehendak penguasa negara mengenai hukum yang berlaku di wilayahnya dan mengenai arah perkembangan hukum yang dibangun. ${ }^{9}$ Pernyataan tentang "hukum yang berlaku di wilayahnya" mengandung pengertian hukum yang berlaku pada saat ini (ius constitutum) dan pernyataan tentang "arah perkembangan hukum yang dibangun" mengandung pengertian bahwa politik hukum juga berkenaan dengan hukum yang dicita-citakan (ius constituendum). ${ }^{10}$

Menurut Satjipto Rahardjo, politik hukum sebagai aktivitas memilih dan cara yang hendak dipakai untuk mencapai suatu tujuan sosial dan hukum tertentu dalam masyarakat. ${ }^{11}$

Selanjutnya Padmo Wahjono dalam bukunya "Indonesia Negara Berdasarkan Atas Hukum" 12 mendefinisikan politik hukum sebagai kebijakan dasar yang menentukan arah, bentuk, maupun isi dari hukum yang akan dibentuk. Kemudian Padmo menambahkan lagi bahwa politik hukum juga akan berkaitan dengan masalah kebijakan penyelenggara negara tentang apa yang dijadikan untuk menghukumkan sesuatu. Dalam hal ini kebijakan tersebut dapat berkaitan dengan pembentukan hukum, penerapan hukum, dan masalah penegakan hukum itu sendiri. ${ }^{13}$

Mahfud MD mengemukakan bahwa Politik hukum adalah "legal policy atau garis (kebijakan) resmi tentang hukum yang akan diberlakukan baik dengan pembuatan hukum baru maupun dengan penggantian hukum lama, dalam rangka mencapai tujuan negara". ${ }^{14}$

Bagir Manan, menyatakan bahwa politik hukum dapat bersifat tetap (permanen) dan temporer. Politik hukum yang bersifat permanen berkaitan dengan sikap hukum yang akan selalu menjadi dasar kebijaksanaan pembentukan dan penegakan hukum; misalnya terdapatnya satu sistem hukum nasional dengan adanya unifikasi hukum atau berlakunya satu sistem hukum di seluruh wilayah Indonesia. Di samping itu, masyarakat juga

${ }^{8}$ C.F.G. Sunaryati Hartono, Politik Hukum Menuju Satu Sistem Hukum Nasional, (Bandung: Alumni, 1991), hlm.1.

9 Teuku Mohammad Radhie, "Pembaruan dan Politik Hukum dalam Rangka Pembangunan Nasional”, Prisma No. 6 Tahun II, Desember 1973, hlm. 3, dikutip dalam Ibid.

${ }^{10}$ Dikutip dalam Imam Syaukani dan A. Ahsin Thohari, Dasar-dasar Politik Hukum, Cetakan ke-9 (Jakarta: Raja Grafindo Persada, 2013), hlm. 27.

${ }^{11}$ Satjipto Rahardjo, Ilmu Hukum, Cet III, (Bandung: Citra Aditya Bakti, 1991), hlm. 352.

12 Padmo Wahjono, Indonesia Negara Berdasarkan Atas Hukum, Cet II, (Jakarta: Ghalia Indonesia, 1986), hlm. 160.

${ }^{13}$ Ibid.

${ }^{14}$ Moh. Mahfud MD, Politik Hukum Di Indonesia, (Jakarta: Rajagrafindo persada, 2012), hlm. 1 . 
memiliki peran yang sangat penting dalam pembentukan hukum; seperti hukum adat dan hukum yang tidak tertulis lainnya yang diakui sebagai subsistem hukum nasional sepanjang nyata-nyata hidup dan dipertahankan dalam pergaulan masyarakat. Sedangkan politik hukum yang bersifat temporer adalah kebijaksanaan yang ditetapkan dari waktu ke waktu sesuai dengan kebutuhan. ${ }^{15}$

Pengertian mengenai praktek monopoli yaitu suatu pemusatan kekuatan ekonomi oleh satu/lebih pelaku usaha yang mengakibatkan dikuasainya produksi/pemasaran atas barang jasa/jasa tertentu sehingga menimbulkan persaingan usaha tidak sehat dan dapat merugikan kepentingan umum.

Pemusatan kekuatan ekonomi adalah penguasaan yang nyata atas suatu pasar bersangkutan oleh satu/lebih pelaku usaha sehingga dapat menentukan harga barang/jasa.

Persaingan usaha tidak sehat adalah persaingan antar pelaku usaha dalam menjalankan kegiatan produksi/ pemasaran barang/ jasa yang dilakukan dengan cara tidak jujur/ melawan hukum / menghambat persaingan usaha.

Dari pengertian yang diberikan di atas jelas dapat kita lihat bahwa salah satu prasyarat pokok dapat dikatakan telah terjadi suatu pemusatan kekuatan ekonomi adalah telah terjadinya penguasaan nyata dari suatu pasar bersangkutan sehingga harga dari barang/jasa yang diperdagangkan tidak lagi mengikuti hukum ekonomi mengenai permintaan dan penjualan, melainkan semata-mata ditentukan oleh satu/lebih pelaku ekonomi yang menguasai pasar tersebut.

Sebagai suatu kenyataan kita memang tidak dapat menghindarkan diri dari praktek monopoli yang sekarang ada di sekitar kita. Monopoli sudah merupakan konsekuensi logis atas pemilikan sistem-sistem ekonomi yang ada. Kemunculannya dapat terjadi dalam berbagai bentuk dan cara seperti $;^{16}$ a. Monopoli by law.

Ia tumbuh karena dikehendaki oleh hukum, UUD 1945 Pasal 33 juga membenarkan adanya monopoli jenis ini, yaitu dengan memberi monopoli bagi negara untuk menguasai bumi dan air dan kekayaan alam yang terkandung di dalamnya serta cabang-cabang produksi yang menguasai hajat hidup orang banyak. Contoh: PLN, Kereta Api, Pertamina, dll.

b. Monopoli by nature.

15 Pendapat Bagir Manan sebagaimana dikutip oleh Kotan Y. Stefanus, Perkembangan Kekuasaan Pemerintahan Negara, dapat diakses pada https://balianzahab.wordpress.com/makalah-hukum/politik-hukum/apa-politik-hukum-itu/

${ }^{16}$ Ahmad Yani dan Gunawan Widjaja, Anti Monopoli, (Jakarta: Rajawali Pers, 2006), hlm. 56. 
Yaitu monopoli yang lahir dan tumbuh secara alamiah karena didukung oleh iklim dan lingkungan yang cocok. Contoh, perusahaan yang karena memiliki keunggulan dan kekuatan tertentu dapat menjadi bisnis raksasa yang menguasai seluruh pasar yang ada.

c. Monopoli by license.

Monopoli yang diperoleh melalui lisensi dengan menggunakan mekanisme kekuasaan. Contoh: waralaba KFC, Mc Donald, Coca Cola, Pepsi, dll.

\section{Politik Hukum Sebelum Pembentukan Undang-Undang Larangan Praktek Monopoli dan Persaingan Usaha Tidak Sehat tahun 1999.}

Pada masa sebelum reformasi (sebelum pembentukan UndangUndang Nomor 5 Tahun 1999), perekonomian didominasi oleh struktur yang terkonsentrasi. Pelaku usaha yang memiliki akses terhadap kekuasaan dapat menguasai dengan skala besar perekonomian Indonesia. Struktur monopoli dan oligopoli sangat mendominasi sektor-sektor ekonomi saat itu. Dalam perkembangannya, pelaku-pelaku usaha yang dominan bahkan berkembang menjadi konglomerasi dan menguasai dari hulu ke hilir di berbagai sektor. Disamping struktur yang terkonsentrasi, situasi perekonomian Indonesia ketika itu banyak diwarnai pula oleh berbagai bentuk perilaku anti persaingan, seperti perilaku yang berupaya memonopoli atau menguasai sektor menguasai sektor tertentu, melalui kartel, penyalahan posisi dominan, merger/take over, diskriminasi, dan sebagainya.

Berdasarkan perkembangan perekonomian nasional di Indonesia selama 3 (tiga) dasawarsa sebelum Tahun 1999 menunjukan bahwa kebijakan yang diterapkan di bidang perekonomian kurang mengacu kepada amanat Pasal 33 Undang-Undang Dasar Negara Republik Indonesia Tahun 1945, bahkan cenderung menunjukan corak yang sangat monopolistik. Keadaan tersebut antara lain disebabkan para pelaku usaha yang dekat dengan elit kekuasaan, mendapat kemudahan yang berlebihan, sehingga berdampak kepada kesenjangan sosial. Kesenjangan sosial yang berkepanjangan berbarengan dengan timbulnya krisis moneter, mendorong Pemerintah untuk mencari jalan keluar dari kemelut yang ada. Oleh karena itu, agar perekonomian dapat tumbuh dan berkembang secara sehat sehingga dapat tercipta iklim usaha yang kondusif dan tidak terjadi pemusatan kekuatan ekonomi pada perorangan atau kelompok tertentu dan dapat dicegah adanya praktek monopoli dan persaingan usaha tidak sehat, maka Pemerintah merasa perlu ada Undang-Undang yang mengatur persaingan usaha yang sehat dan dapat memberikan perlindungan hukum yang sama bagi setiap pelaku usaha.

Akibatnya, kinerja ekonomi nasional cukup memprihatinkan. Hal tersebut ditandai dengan pilihan bagi konsumen yang terbatas, kelangkaan 
pasokan, harga yang tak terjangkau, lapangan kerja yang terbatas, pertumbuhan industri yang lambat, daya saing produk melemah, serta kesenjangan ekonomi dalam berbagai bidang kehidupan rakyat. Kondisi ini berujung pada runtuhnya bangunan ekonomi Indonesia, yang telah dibangun selama puluhan tahun terhapus hanya dalam waktu singkat pada saat krisis 1997.

Ada beberapa alasan mengapa pada masa orde baru sulit sekali suatu Undang-Undang Anti Monopoli disetujui oleh Pemerintah, yaitu ${ }^{17}$ :

a. pemerintah menganut konsep bahwa perusahaan-perusahaan besar perlu ditumbuhkan untuk menjadi lokomotif pembangunan. Perusahaanperusahaan tersebut hanya mungkin menjadi besar untuk kemudian menjalankan fungsinya sebagai lokomotif pembangunan apabila diberi perlakuan khusus. Perlakuan khusus ini, dalam pemberian proteksi yang dapat menghalangi masuknya perusahaan lain dalam bidang usaha tersebut atau dengan kata lain memberikan posisi monopoli;

b. pemberian fasilitas monopoli perlu ditempuh karena perusahaan itu telah bersedia menjadi pioner di sektor yang bersangkutan. Tanpa fasilitas monopoli dan proteksi,Pemerintah sulit memperoleh kesediaan investor untuk menanamkan modalnya di sektor tersebut; dan c. untuk menjaga berlangsungnya praktek KKN demi kepentingan kroni mantan Presiden Soeharto dan pejabat-pejabat yang berkuasa pada waktu itu.

Kebijakan pembangunan ekonomi yang kita jalankan selama tiga dasawarsa, selain menghasilkan banyak kemajuan, yang ditunjukan oleh pertumbuhan ekonomi yang tinggi, juga masih banyak melahirkan tantangan atau persoalan pembangunan ekonomi yang belum terpecahkan. Di samping itu, ada kecenderungan globalisasi perekonomian serta dinamika dan perkembangan usaha swasta sejak awal tahun 1990-an. Peluang-peluang usaha yang telah diciptakan oleh penguasa pada waktu itu dalam kenyataannya belum membuat seluruh masyarakat mampu dan dapat berpartisipasi dalam pembangunan di berbagai sektor ekonomi.

Perkembangan usaha swasta, di satu sisi diwarnai oleh berbagai bentuk kebijakan penguasa yang kurang tepat, sehingga pasar menjadi terdistorsi. Di sisi lain, sebagian besar perkembangan usaha swasta pada kenyataannya merupakan perwujudan dari kondisi persaingan usaha yang tidak sehat atau curang. Fenomena yang demikian telah berkembang dan didukung oleh adanya hubungan antara pengambil keputusan dan para pelaku usaha, baik secara langsung maupun tidak langsung. Keadaan ini

${ }^{17}$ Sutan Remy Sjahdeini, "Larangan Praktek Monopoli dan Persaingan Usaha Tidak Sehat” Jurnal Hukum Bisnis Volume 10, Yayasan Pengembangan Hukum Bisnis, Jakarta, 2000, hlm 5. 
makin memperburuk keadaan. Penyelenggaraan ekonomi nasional kurang memperhatikan amanat Pasal 33 Undang-Undang Dasar 1945, serta cenderung menunjukan corak yang sangat monopolistik. Para pengusaha yang dekat dengan elit kekuasaan mendapatkan kemudahan-kemudahan yang berlebihan, sehingga menimbulkan kesenjangan sosial. Munculnya konglomerasi dan sekelompok kecil pengusaha kuat yang tidak didukung oleh semangat kewirausahaan sejati merupakan salah satu faktor yang mengakibatkan ketahanan ekonomi menjadi sangat rapuh dan tidak mampu bersaing. Padahal dalam era pasar bebas, akan dituntut untuk mampu bersaing dengan mengandalkan kekuatan sendiri. Lebih ironis lagi, perilaku dari pelaku-pelaku bisnis kita, yaitu para konglomerat yang telah memperoleh perlakuan istimewa dari penguasa tersebut, ternyata sangat tidak bertanggungjawab, dan tidak mau berbuat positif untuk memperbaiki kondisi ekonomi nasional yang sangat parah.

Kondisi tersebut pada akhirnya mendorong dilakukannya reformasi di sektor ekonomi, sebagai bagian dari reformasi di berbagai bidang kehidupan bernegara dan berbangsa. Sebagaimana diketahui, secara garis besar terdapat tiga hal penting yang menjadi inti dari perubahan yang disepakati oleh bangsa ini saat reformasi digulirkan, yang memiliki efek luar biasa bagi perkembangan bangsa ini ke depan.

\section{Politik Hukum Setelah Berlakunya Undang-Undang Larangan Praktek Monopoli dan Persaingan Usaha Tidak Sehat tahun 1999}

Dalam pembahasan permasalahan tersebut di atas, penulis membatasi pembatasan masalah pada Kebijakan Hukum Persaingan, karena penulis berpijak pada pendapat Mahfud M.D yang mengemukakan bahwa politik hukum adalah "legal policy atau garis (kebijakan) resmi tentang hukum yang akan diberlakukan baik dengan pembuatan hukum baru maupun dengan penggantian hukum lama, dalam rangka mencapai tujuan negara". ${ }^{18}$

Dengan demikian, politik hukum merupakan pilihan tentang hukumhukum yang akan diberlakukan sekaligus pilihan tentang hukum-hukum yang akan dicabut atau tidak diberlakukan yang kesemuanya dimaksudkan untuk mencapai tujuan negara seperti yang tercantum di dalam pembukaan UUD 1945. ${ }^{19}$ Politik hukum dimaknai sebagai keseluruhan proses pembuatan dan pelaksanaan hukum yang menunjukan sifat dan kearah mana hukum akan dibangun dan ditegakkan.

\footnotetext{
${ }^{18}$ Moh. Mahfud MD, Politik Hukum Di Indonesia, (Jakarta: Rajagrafindo Persada, 2012), hlm. 1 .

${ }^{19}$ Ibid.
} 
Hukum merupakan produk politik, maka karakter produk hukum berubah jika konfigurasi politik yang melahirkannya berubah. ${ }^{20}$

Dalam sepanjang sejarah republik Indonesia telah terjadi perubahanperubahan politik secara bergantian (berdasar periode sistem politik) antara konfigurasi politik yang demokratis dan konfigurasi politik yang otoriter. Sejalan dengan perubahan-perubahan konfigurasi politik itu, karakter produk hukum juga berubah. Pada saat konfigurasi politik tampil secara demokratis, maka produk-produk hukum yang dilahirkannya berkarakter responsif, sebaliknya ketika konfigurasi politik tampil secara otoriter, hukum-hukum yang dilahirkannya berkarakter ortodoks. Hubungan kausalitas tersebut berlaku untuk hukum-hukum publik yang berkaitan dengan gezagsverhouding dengan tingkat sensitifitas yang berbeda-beda. Semakin kental muatan hukum dengan masalah hubungan kekuasaan, semakin kuat pula pengaruh konfigurasi politik terhadap hukum tersebut. ${ }^{21}$

Di Indonesia istilah yang sering digunakan adalah hukum persaingan atau anti monopoli. Di Indonesia hukum anti monopoli diatur dalam Undang-Undang Nomor 5 Tahun 1999 tentang Larangan Prakek Monopoli dan Persaingan Usaha Tidak Sehat. Undang-undang ini merupakan pengaturan secara khusus dan komprehensif yang berkaitan dengan persaingan antar pelaku usaha.

Secara teoritik globalisasi ekonomi dengan makna keterbukaan dengan persaingan bebas memang merupakan suatu the best solution dalam hubungan ekonomi antar negara dan memakmurkan umat manusia. Persaingan akan memaksa masing-masing pihak mencari metode produksi yang paling efisien. Produk yang dihasilkan dengan efisien akan dapat dijual dengan harga murah.

Guna mewujudkan keinginan adanya Undang-Undang yang mengatur persaingan usaha yang sehat tersebut, Dewan Perwakilan Rakyat Republik Indonesia dan Pemerintah pada Tahun 1999 telah membentuk Undang-Undang tentang Larangan Praktek Monopoli dan Persaingan Usaha Tidak Sehat yang kemudian menjadi Undang-Undang Nomor 5 Tahun 1999 yang diundangkan pada tanggal 5 Maret Tahun 1999.

Selain alasan objektif dan rasional sebagaimana dipaparkan di atas, lahirnya Undang-Undang Nomor 5 Tahun 1999 adalah sejalan dengan semangat Pancasila dan Undang-Undang Dasar Tahun 1945, khususnya Pasal 27, Pasal 31, Pasal 33, dan Pasal 34. Hal ini dapat dilihat dari bunyi Pasal 2 dan Pasal 3 Undang-Undang Nomor 5 Tahun 1999 mengenai asas dan tujuan pembentukan Undang-Undang Nomor 5 Tahun 1999. Pasal 2 menyatakan bahwa pelaku usaha di Indonesia dalam menjalankan kegiatan

\footnotetext{
${ }^{20}$ Op.cit, hlm. 373.

${ }^{21}$ Ibid.
} 
usahanya berasaskan demokrasi ekonomi dengan memperhatikan keseimbangan antara kepentingan pelaku usaha dan kepentingan umum.

Sedangkan tujuan pembentukan Undang-Undang Nomor 5 Tahun 1999 adalah sebagaimana tercantum dalam Pasal 3, yang sesungguhnya memiliki tujuan akhir yang sama, yakni peningkatan kesejahteraan masyarakat. Dalam Pasal 3 disebutkan bahwa tujuan pembentukan UndangUndang Nomor 5 Tahun 1999 adalah:

a. menjaga kepentingan umum dan meningkatkan efisiensi ekonomi nasional sebagai salah satu upaya untuk meningkatkan kesejahteraan rakyat;

b. mewujudkan iklim usaha yang kondusif melalui pengaturan persaingan usaha yang sehat sehingga menjamin adanya kepastian kesempatan berusaha yang sama bagi pelaku usaha besar, pelaku usaha menengah, dan pelaku usaha kecil;

c. mencegah praktek monopoli dan atau persaingan usaha tidak sehat yang ditimbulkan oleh pelaku usaha; dan

d. terciptanya efektivitas dan efisiensi dalam kegiatan usaha.

Secara substansi Undang-Undang Nomor 5 Tahun 1999 pada dasarnya berisi larangan terhadap perjanjian, kegiatan dan posisi dominan yang bertentangan dengan prinsip persaingan usaha yang sehat. Pengaturan ini dilakukan dengan sangat ketat untuk mencegah pelaku usaha melakukan persaingan usaha tidak sehat yang dipandang akan merugikan bagi masyarakat dan bangsa Indonesia.

Untuk mencegah terjadinya monopoli dan/atau persaingan usaha tidak sehat, Undang-Undang melarang dilakukan tindakan-tindakan tertentu oleh para pelaku usaha. Secara garis besar tindakan-tindakan tersebut dapat digolongkan ke dalam dua kategori.

Pertama, tindakan yang dilakukan dalam rangka kerja sama dengan sesama pelaku usaha ekonomi, sebagaimana diatur dalam tabel berikut;

\begin{tabular}{|l|l|}
\hline Pasal 4 & Oligopoli; \\
\hline Pasal 5-8 & penetapan harga secara bersama; \\
\hline Pasal 9 & pembagian wilayah secara bersama; \\
\hline Pasal 10 & kerja sama pemboikotan; \\
\hline Pasal 11 & pembentukan kartel; \\
\hline Pasal 12 & Trust; \\
\hline Pasal 13 & Oligopsoni; \\
\hline Pasal 14 & integrasi vertikal; \\
\hline Pasal 15 & perjanjian tertutup; dan \\
\hline Pasal 16 & perjanjian dengan pihak di luar negeri. \\
\hline
\end{tabular}


Kedua, tindakan hukum yang dilakukan oleh pelaku usaha/kelompok pelaku usaha tersebut, tanpa melibatkan pelaku usaha/kelompok pelaku usaha lainnya, dalam UU dibagi ke dalam tabel berikut:

\begin{tabular}{|l|l|}
\hline Pasal 17 & monopoli \\
\hline Pasal 18 & monopsoni \\
\hline Pasal 19-21 & penguasaan pasar \\
\hline Pasal 22 & persekongkolan \\
\hline
\end{tabular}

Dari konsideran Undang-Undang Nomor 5 Tahun 1999, dapat diketahui falsafah yang menjadi arah kelahirannya dan sekaligus memuat dasar pikiran perlunya disusun undang-undang tersebut. Setidaknya memuat tiga hal, yaitu:

a. bahwa pembangunan bidang ekonomi harus diarahkan kepada terwujudnya kesejahteraan rakyat berdasarkan Pancasila dan Undang-Undang Dasar 1945;

b. bahwa demokrasi dalam bidang ekonomi menghendaki adanya kesempatan yang sama bagi setiap warga negara untuk berpartisipasi di dalam proses produksi dan pemasaran barang dan/atau jasa, dalam iklim usaha yang sehat, efektif, dan efisien, sehingga dapat mendorong pertumbuhan ekonomi dan bekerjanya ekonomi pasar yang wajar;

c. Bahwa setiap orang yang berusaha di Indonesia harus berada dalam situasi persaingan yang sehat dan wajar, sehingga tidak menimbulkan adanya pemusatan kekuatan ekonomi pada pelaku usaha tertentu, dengan tidak terlepas dari kesepakatan yang telah dilaksanakan oleh Negara Republik Indonesia terhadap perjanjian-perjanjian internasional.

Sementara itu Penjelasan Umum Undang-Undang Nomor 5 Tahun 1999 juga menyatakan antara lain "Memperhatikan situasi dan kondisi tersebut di atas, menuntut kita untuk mencermati dan menata kembali kegiatan usaha di Indonesia, agar dunia usaha dapat tumbuh serta berkembang secara sehat dan benar, sehingga tercipta iklim persaingan usaha yang sehat serta terhindarnya pemusatan kekuatan ekonomi pada perorangan atau kelompok tertentu, antara lain dalam bentuk praktek monopoli dan persaingan usaha tidak sehat yang merugikan masyarakat, yang bertentangan dengan cita-cita keadilan sosial. Oleh karena itu, perlu disusun undang-undang tentang larangan praktek monopoli dan persaingan usaha tidak sehat yang dimaksudkan untuk menegakan aturan hukum dan memberikan perlindungan yang sama bagi setiap pelaku usaha di dalam upaya untuk menciptakan persaingan usaha yang sehat.

Undang-undang ini memberikan jaminan kepastian hukum untuk lebih mendorong percepatan pembangunan ekonomi dalam upaya meningkatkan kesejahteraan umum, serta sebagai implementasi dari semangat dan jiwa 
Undang-Undang Dasar 1945. Dengan demikian kelahiran Undang-Undang Nomor 5 Tahun 1999 ini dimaksudkan untuk memberikan jaminan kepastian hukum dan perlindungan yang sama kepada setiap pelaku usaha dalam berusaha, dengan cara mencegah timbulnya praktek-praktek monopoli dan/atau persaingan usaha yang tidak sehat lainnya dengan harapan dapat menciptakan iklim usaha yang kondusif, di mana setiap pelaku usaha dapat bersaing secara wajar dan sehat. Untuk itu diperlukan aturan hukum yang pasti dan jelas yang mengatur larangan praktek monopoli dan persaingan usaha tidak sehat lainnya.

Kebijakan persaingan usaha sebagai alat politik menuju negara yang kuat. Koreksi negara untuk kembali kepada amanat UUD 1945 Pasal 33 terefleksikan dalam Undang-Undang No. 5 Tahun 1999 tentang Larangan Praktek Monopoli dan Persaingan Usaha Tidak Sehat. Undangundang ini dapat menjadi alat politik yang tepat untuk mengendalikan peran swasta dengan cara yang halus. Karena undang-undang ini disusun dengan semangat dan jiwa UUD 1945. Undang-Undang No. 5 Tahun 1999 dirancang untuk memberikan jaminan kepastian hukum untuk mendorong percepatan pembangunan industri dan menempatkan posisi negara sebagai regulator yang kuat.

Peluang untuk memposisikan kembali pemerintah reformasi sebagai negara yang kuat (strong state), dalam kerangka hubungan negara dan pengusaha dapat tercapai seandainya lembaga-lembaga penyelenggara negara seperti KPPU, Departemen Perindustrian dan Departemen Perdagangan menjalankan fungsinya dengan benar. Yaitu menciptakan kelembagaan yang menjadi landasan dan tumpuan setiap individu dalam masyarakat yang otonom, bebas, sejahtera, dan tertib. ${ }^{22}$ Termasuk di dalamnya memberikan rasa percaya bahwa negara mampu melindungi masyarakat secara adil.

Dalam pandangan Fukuyama, negara harus dilihat dalam dua dimensi yang berbeda, yaitu kekuatannya (strength) dan cakupan (scope) peranannya. Suatu negara yang kuat akan mampu melahirkan kebijakan dan aturan-aturan yang ditaati oleh masyarakat, tanpa menebarkan rasa ketakutan kecemasan dan paksaan yang berlebihan. Ciri negara seperti ini dapat dilakukan dengan intervensi yang minimal dalam mengatur tata kelola industri, dan sebaliknya dapat juga bersifat ekspansif dengan dukungan kelembagaan yang mengakar dan bekerja efektif.

Oleh karena itu, Undang-Undang No. 5 Tahun 1999 tentang Larangan Praktek Monopoli dan Persaingan Usaha Tidak Sehat merupakan salah

${ }^{22}$ Lihat tulisan Francis Fukuyama yang berjudul State Building-Governance and World Order in Twenty Century dalam Rizal Mallarangeng "Mendobrak Sentralisme Ekonomi: Indonesia 1986-1992, Cetakan Kedua, Jakarta: Freedom Institute (Center For Democracy, Nationalisme, and Market Economy Studies)-KPG, 2004, hlm. xii. 
satu upaya pemerintah untuk membentuk kembali negara yang kuat, negara yang aturan-aturannya dipatuhi oleh masyarakat untuk mencapai kemakmuran masyarakat. Untuk membentuk negara yang kuat dalam bingkai liberalisasi, memang negara tidak harus sebagai operator, tetapi cukup memposisikan negara sebagai regulator yang mengontrol perilaku masyarakatnya.

Lahirnya Undang-Undang Nomor 5 Tahun 1999 tentang Larangan Praktek Monopoli dan Persaingan Usaha Tidak Sehat, pada dasarnya merupakan bentuk koreksi negara untuk menata kembali menjadi negara yang lebih tertib berwibawa, dan kuat di hadapan pengusaha kapitalis Indonesia. Namun demikian, pada saat yang bersamaan pascajatuhnya rezim Orde Baru tahun 1998, Indonesia mengalami perubahan pada masyarakatnya, dari masyarakat yang lemah menuju masyarakat yang kritis dan kuat (strong society).

Kebutuhan akan pentingnya Hukum Persaingan Usaha di Indonesia merupakan salah satu prasyarat akan berjalannya sistem ekonomi demokrasi yang berdasarkan Pancasila. Pembentukan UU No. 5 Tahun 1999 tidak lepas dari pertimbangan akan harapan meningkatnya pertumbuhan ekonomi nasional. Secara filosofis, undang-undang ini juga merefleksikan kondisi perekonomian Indonesia. Salah satu tujuan dari lahirnya UU No. 5 Tahun 1999 ialah untuk mewujudkan iklim usaha yang kondusif melalui pengaturan persaingan usaha yang sehat sehingga menjamin adanya kepastian kesempatan berusaha yang sama bagi pelaku usaha besar, pelaku usaha menengah, dan pelaku usaha kecil. Selain itu, UU No. 5 Tahun 1999 juga bertujuan untuk menciptakan efektivitas dan efisiensi dalam kegiatan usaha. Ketika tujuan tersebut terpenuhi, stabilitas perekonomian dan kepastian hukum menjadi lebih terjamin.

Masyarakat pada saat ini, jauh lebih kritis dibandingkan dengan pada masa Orde Baru. Temuan-temuan praktek monopoli dan persaingan usaha tidak sehat sebagian besar merupakan hasil temuan masyarakat yang dilaporkan kepada KPPU. Hal ini menunjukan fungsi pengawasan sosial (social control) masyarakat terhadap swasta yang berindikasi melawan hukum persaingan usaha telah berjalan dengan baik. Fenomena ini menunjukan terjadinya penguatan fungsi kontrol masyarakat (strong society).

Politik hukum dalam pembentukan Undang-Undang Persaingan Usaha dapat dilihat juga dalam kondisi yang mengharuskan pemerintah mencari bantuan dari donor-donor lain, baik yang bersifat kolektif maupun negara per negara. Ketergantungan pada bantuan asing, ini mengharuskan pemerintah mengikuti berbagai persyaratan yang disepakati bersama, semuanya meletakan Indonesia pada posisi yang lemah. Walau demikian, dalam hal-hal tertentu, banyak hal yang berkaitan dengan persyaratan utang luar negeri itu yang mengandung hikmah, yaitu 
mengakselerasi pembuatan undang-undang yang sebenarnya sudah lama didambakan, yang dalam kondisi normal tidak akan dibentuk pada umumnya ini telah terjadwal di antara Indonesia dengan IMF. ${ }^{23}$

Di samping Politik hukum merupakan tuntutan nasional, UndangUndang Persaingan Usaha (Fair Competition Law) juga merupakan tuntutan atau kebutuhan rambu-rambu yuridis dalam hubungan bisnis antar bangsa. Dari sisi kehidupan nasional jelas bahwa basis kultural (asas kekeluargaan) dan konstitusional (demokrasi ekonomi) kita memang sama sekali menolak praktek-praktek monopolistik dalam kehidupan ekonomi yang merugikan rakyat. Dari sisi hubungan antar bangsa pun, apalagi dengan munculnya fenomena globalisasi ekonomi yang mengandung makna, semakin meningkatnya ketergantungan antar bangsa di berbagai bidang kehidupan (ekonomi), mengharuskan berbagai bangsa menaati ramburambu (peraturan) baku dalam bisnis antar bangsa, sebagai konsekuensi WTO, APEC, AFTA, NAFTA, EC, dan lain sebagainya. ${ }^{24}$

Sebab, para ahli banyak yang mengatakan, adanya kondisi persaingan (the state of competition) dalam pasar domestik merupakan hal yang sangat penting dari suatu kebijakan publik (public policy), khususnya untuk mengukur kemampuan bangsa dalam bersaing di pasar internasional, serta untuk meyakinkan investor dan eksportir asing untuk bersaing dalam pasar domestik. Dengan demikian, tujuan dari kebijakan persaingan nasional adalah untuk menciptakan dan memastikan bahwa konsep persaingan dapat dijalankan dalam kerangka ekonomi pluralistik. Konsep dasar kompetitif ini pun pada dasarnya mengandung unsur HAM yang kental, karena di dalamnya terkait pemajuan (promotion) dari kondisi persaingan (condition of rivalry), dan kebebasan memilih (freedom of choose) untuk mengurangi dan melarang konsentrasi kekuatan-kekuatan ekonomi. ${ }^{25}$

Untuk itulah, akhirnya harus ada campur tangan negara (government regulation) untuk mengembangkan dan memelihara kondisi persaingan. Bahkan globalisasi menciptakan atmosfer yang kondusif untuk persaingan yang menembus batas-batas negara, yang membutuhkan harmonisasi kebijakan yang sering dinamakan Super National Of Regional Standards. Bahkan Masyarakat Ekonomi Eropa (EC) juga masih terus mengembangkan apa yang dinamakan Minimum Competition Policy Requirements Within the Framework of the GATT. Di lingkungan ASEAN pun, tanpa mengesampingkan divergensi struktur institusional ekonomi, politik, dan sosial, para ahli sudah mulai berpikir tentang perlunya pengembangan di

\footnotetext{
${ }^{23}$ Muladi, "Menyongsong Keberadaan UU Persaingan Sehat di Indonesia", dalam UU Anti monopoli Seperti Apakah yang Sesungguhnya Kita Butuhkan?Newsletter Nomor 34 Tahun IX, (Jakarta: Yayasan Pusat Pengkajian Hukum), hlm. 35-36.

${ }^{24}$ Ibid, hlm. 36.

${ }^{25}$ Ibid.
} 
samping hukum persaingan nasional dan harmonisasi peraturan-peraturan komersial, termasuk hukum persaingan di antara masyarakat ASEAN. ${ }^{26}$

\section{Politik Hukum Persaingan Usaha di Masa Yang Akan Datang}

Doktrin yang berlaku pada masa lalu, yang secara absolut menyatakan bahwa hukum ekonomi itu bersifat value loaded, yang dekat dengan kondisi sosial budaya bangsa, tidak sepenuhnya dapat dipertanggungjawabkan dalam kaitannya dengan proses globalisasi. Konsep harmonisasi hukum dan keberadaan fenomena internasionalisasi pasar menumbuhkan perhatian yang semakin intensif terhadap apa yang dinamakan international dimension of antitrust and the fit between competition policy and the world trading system. Dalam kerangka ini, muncul antitrust family (international) link ages of market economies. ${ }^{27}$

Pendapat Richard A. Posner menengahi pendapat Cheryl W. Gray dan Leonard J. Theberge. Posner dalam tulisannya "Creating a Legal Framework for Economic Development ${ }^{\text {"28 }}$ menyatakan bahwa negara-negara berkembang mau tidak mau harus mengadopsi hukum asing dan kemudian melakukan modifikasi terhadap hukum asing tersebut. Menurut Posner, hukum itu efisien jika secara substansi, hukum dapat mempromosikan alokasi yang efektif atas semua sumber daya ekonomi (kepada pasar). Di sisi lain, hukum itu efisien apabila secara prosedural mampu mengurangi cost (pengeluaran) dan meningkatkan akurasi dan pemakaian sistem hukum. Menurut Posner, dan juga didukung oleh para ahli ekonomi lainnya, apabila hukum itu menghalangi investor untuk berinvestasi, maka aturan hukum tersebut tidaklah efisien.

Pendapat Posner memberikan peluang bagi negara berkembang untuk melakukan Legal Borrowing. Legal Borrowing adalah meniru seluruh atau sebagian dari hukum negara lain, untuk kemudian disesuaikan dengan corak hukum yang berlaku di dalam masyarakat negara yang bersangkutan.

Semangat Pasal 27 ayat (2) dan Pasal 33 UUD 1945 merupakan cerminan semangat yang harus diemban oleh UU Persaingan. Oleh karena itu, perwujudan demokrasi ekonomi dan kesejahteraan rakyat mutlak merupakan amanat dari konstitusi yang perlu diwujudkan melalui UU Persaingan ini.

Demokrasi ekonomi menghendaki adanya jaminan atas kesempatan yang sama bagi setiap warga negara untuk berpartisipasi dalam kegiatan ekonomi melalui iklim persaingan usaha yang sehat sehingga tercipta efisiensi dan inovasi yang menyebabkan ekonomi pasar berjalan dalam

\footnotetext{
${ }^{26}$ Ibid.., hlm 37.

${ }^{27}$ Ibid.., hlm,37-38.

${ }^{28}$ Richard A. Posner, "Creating a Legal Framework for Economic Development”, The World Bank Research Observer, vol. 13, No. 1 (February 1998).
} 
kewajaran. Iklim persaingan usaha yang sehat juga dapat mencegah pemusatan kekuatan ekonomi oleh satu atau beberapa pihak saja dalam sektor ekonomi tertentu.

Kehadiran Undang-Undang Nomor 5 Tahun 1999 sebagai toolof social control and a tool of social engineering. Sebagai "alat kontrol sosial", Undang-Undang Nomor 5 Tahun 1999 berusaha menjaga kepentingan umum dan mencegah praktek monopoli dan/atau persaingan usaha tidak sehat. Selanjutnya sebagai "alat rekayasa sosial", Undang-Undang Nomor 5 Tahun 1999 berusaha untuk meningkatkan efisiensi ekonomi nasional, mewujudkan iklim usaha yang kondusif melalui pengaturan persaingan usaha yang sehat, dan berusaha menciptakan efektivitas dan efisiensi dalam kegiatan usaha. ${ }^{29}$

Sebagaimana telah dikemukakan sebelumnya konsepsi hukum sebagai sarana pembangunan masyarakat dikemukakan oleh Mochtar Kusumaatmadja yang menyatakan ${ }^{30}$ : Bahwa hukum merupakan sarana pembaharuan masyarakat. Hal ini di dasarkan pada satu anggapan bahwa adanya ketentuan atau ketertiban itu merupakan suatu hal yang diinginkan, bahwa dipandang perlu. Konsepsi hukum sebagai sarana pembaharuan masyarakat adalah hukum dalam arti kaidah atau peraturan hukum memang dapat berfungsi sebagai alat (pengatur) atau sarana pembangunan dalam arti penyalur arah kegiatan manusia ke arah yang dikehendaki oleh pembangunan atau pembaharuan. Lebih tegas bahwa dalam proses pembangunan hukum harus berada di depan bukan berada mengikuti pembangunan atau pembaharuan, oleh karenanya dipandang hukum sebagai sarana atau alat pembangunan masyarakat. Konsepsi ini sejalan dengan Roscoe Pound dengan "law as tool of social engineering".

W. Friedman menyatakan "Hukum sebagai sarana rekayasa sosial, hukum tidak pasif melainkan harus mampu digunakan untuk mengubah suatu keadaan dan kondisi tertentu ke arah yang dituju sesuai dengan kemauan masyarakatnya". ${ }^{31}$

Apabila cita-cita ideal tersebut dapat dioperasionalkan dalam kehidupan nyata, Undang-Undang Nomor 5 Tahun 1999 akan membawa nilai positif bagi perkembangan iklim usaha di Indonesia, yang selama ini dapat dikatakan jauh dari kondisi ideal. Sekurang-kurangnya, UndangUndang Nomor 5 Tahun 1999 secara tidak langsung akan memaksa pelaku usaha untuk lebih efisien dalam mengelola usahanya, karena Undang-Undang Nomor 5 Tahun 1999 juga menjamin dan memberi peluang yang besar kepada pelaku usaha yang ingin berusaha (sebagai

29 Ayudha D. Prayoga et al (Ed), Persaingan Usaha dan Hukum yang Mengaturnya di indonesia, Proyek ELIPS, Jakarta, 2000, hlm. 52-53

${ }^{30}$ Lili Rasjidi, Dasar - Dasar filsafat Hukum, (Bandung: Citra Aditya Bakti, 1996), hlm. 83.

${ }^{31}$ W. Friedman, Legal Theory, (London, Steven \& sons limited, 1960), hlm. 293. 
akibat dilarangnya praktek monopoli dalam bentuk penciptaan barrier to entry). ${ }^{32}$ Hal ini berarti bahwa hanya pelaku usaha yang efisienlah yang dapat bertahan di pasar. ${ }^{33}$

Dampak positif lain dari Undang-Undang Nomor 5 Tahun 1999 adalah terciptanya pasar yang tidak terdistorsi, sehingga menciptakan peluang usaha yang semakin besar bagi para pelaku usaha. Keadaan ini akan memaksa para pelaku usaha untuk lebih inovatif dalam menciptakan dan memasarkan produk (barang dan jasa) mereka. Jika hal ini tidak dilakukan, para konsumen akan beralih kepada produk yang lebih baik dan kompetitif. Ini berarti bahwa, secara tidak langsung Undang-Undang Nomor 5 Tahun 1999 akan memberikan keuntungan bagi konsumen dalam bentuk produk yang lebih berkualitas, harga yang bersaing, dan pelayanan yang lebih baik. Namun, perlu diingat bahwa Undang-Undang Nomor 5 Tahun 1999 bukan merupakan ancaman bagi perusahaan-perusahaan besar yang telah berdiri sebelum undang-undang ini diundangkan, selama perusahaan-perusahaan tersebut tidak melakukan praktek-praktek yang dilarang oleh UndangUndang Nomor 5 Tahun $1999 .{ }^{34}$

Dunia usaha yang sehat yang dikembangkan di Indonesia sebagai suatu sistem hukum ekonomi nasional, tampaknya harus mampu dibedakan dengan sistem ekonomi yang ada di dunia. Dalam era globalisasi sulit dielakan terjadinya persaingan yang ketat, untuk itu pengembangan sistem ekonomi nasional dalam negeri harus mengikuti kaidah-kaidah yang berlaku di dunia internasional.

Politik hukum persaingan usaha di masa yang akan datang tetap sejalan dengan isi Pasal 33 UUD 1945 (amandemen IV), Rencana Pembangunan Jangka Panjang Tahun 2005-2025 yang dituangkan dalam Undang-Undang No. 17 Tahun 2007 yang dimuat pada Arah, Tahapan, dan Prioritas Pembangunan Jangka Panjang Tahun 2005-2025 sebagai upaya untuk mewujudkan bangsa Indonesia yang berdaya saing dinyatakan bahwa: ${ }^{35}$

IV.1 Arah Pembangunan Jangka Panjang Tahun 2005-2025

IV.1.2 Mewujudkan Bangsa yang Berdaya Saing. Untuk memperkuat daya saing bangsa, pembangunan nasional dalam jangka panjang diarahkan untuk:

a. mengedepankan pembangunan sumber daya manusia

\footnotetext{
${ }^{32}$ Barrier to entry; Legal restrictions e.g. Patents, licensing, requirements on entering the market.

${ }^{33}$ Ayudha D. Prayoga et al. (Ed), loc.cit.

${ }^{34}$ Ibid.

35 Lampiran Undang-Undang RI Nomor 17 tahun 2007 tentang Rencana Pembangunan Jangka Panjang Nasional Tahun 2005-2025 Bab IV Arah Tahapan, dan Prioritas Pembangunan Jangka Panjang Tahun 2005-2025.
} 
berkualitas dan berdaya saing;

b. memperkuat perekonomian domestik berbasis keunggulan di setiap wilayah menuju keunggulan kompetitif dengan membangun keterkaitan sistem produksi, distribusi, dan pelayanan di dalam negeri;

c. meningkatkan penguasaan, pemanfaatan, dan penciptaan pengetahuan;

d. membangun infrastruktur yang maju; dan

e. melakukan reformasi di bidang hukum dan aparatur negara.

Reformasi di bidang hukum lebih dititikberatkan kepada: ${ }^{36}$

Pembangunan hukum diarahkan untuk mendukung terwujudnya pertumbuhan ekonomi yang berkelanjutan; mengatur permasalahan yang berkaitan dengan ekonomi, terutama dunia usaha dan dunia industri; serta menciptakan kepastian investasi, terutama penegakan dan perlindungan hukum. Pembangunan hukum juga diarahkan untuk menghilangkan kemungkinan terjadinya tindak pidana korupsi serta mampu menangani dan menyelesaikan secara tuntas permasalahan yang terkait Kolusi, Korupsi, dan Nepotisme (KKN). Pembangunan hukum dilaksanakan melalui pembaruan materi hukum dengan tetap memperhatikan kemajemukan tatanan hukum yang berlaku dan pengaruh globalisasi sebagai upaya untuk meningkatkan kepastian dan perlindungan hukum, penegakan hukum dan hak-hak asasi manusia (HAM), kesadaran hukum, serta pelayanan hukum yang berintikan keadilan dan kebenaran, ketertiban, dan kesejahteraan dalam rangka penyelenggaraan negara yang makin tertib, teratur, lancar, serta berdaya saing global.

Sasaran dan skala prioritas tersebut di atas dapat dicapai melalui Rencana Pembangunan Jangka Menengah (RPJM). Sekarang memasuki Rencana Pembangunan Jangka Menengah ke-2 (2010-2014).

Berdasarkan pelaksanaan, pencapaian, dan sebagai keberlanjutan RPJM ke-1, RPJM ke-2 ditujukan untuk lebih memantapkan penataan kembali Indonesia di segala bidang dengan menekankan upaya peningkatan kualitas sumber daya manusia termasuk pengembangan kemampuan ilmu pengetahuan dan teknologi serta penguatan daya saing perekonomian.

\section{Beberapa Catatan Undang-Undang Larangan Praktek Monopoli dan Persaingan Usaha Tidak Sehat tahun 1999.}

Undang-undang Persaingan Usaha merupakan undang-undang yang sarat akan permasalahan ekonomi sehingga untuk memahami undang-

${ }^{36}$ Ibid. 
undang tersebut membutuhkan tidak saja dalam bidang ilmu hukum namun juga bidang ilmu lain yaitu ilmu ekonomi. Selain masalah penguasaan ilmu, adanya integritas dan moral yang kuat dari para penegak hukum di bidang persaingan usaha merupakan dua hal yang menunjang hukum persaingan usaha memainkan peranannya dalam pembangunan ekonomi. Penegak hukum yang dimaksud adalah Komisi Pengawas Persaingan Usaha (Komisi), Kepolisian, dan Hakim.

Komisi selaku pengawas atas pelaksanaan Undang-UndangPersaingan Usaha memiliki tugas yang maha berat mengingat Undang-Undang ini tergolong baru, sehingga Komisi belum memiliki bekal serta pengalaman yang memadai. Akan tetapi, itu bukan merupakan hambatan melainkan sebuah tantangan agar terlaksananya Hukum Persaingan Usaha sesuai dengan tujuannya.

Pemahaman terhadap persepsi kepentingan dan kepastian hukum yang sama baik bagi penegak keadilan maupun masyarakat adalah penting dalam menentukan kebijaksanaan ataupun keputusan yang menyangkut perdagangan, perekonomian, industri sosial, dan politik Undang-Undang Nomor 5 Tahun 1999 tentang Larangan Praktek Monopoli dan Persaingan Usaha Tidak Sehat menjadi parameter penegakan hukum ekonomi tersendiri dalam dunia usaha di Indonesia. Undang-undang ini mengamanatkan pembentukan suatu komisi yang berkompeten melakukan pengawasan-pengawasan terhadap pelaksanaan UndangUndang Nomor 5 Tahun 1999, yaitu Komisi Pengawasan Persaingan Usaha (KPPU) yang didirikan Juni 2000 dengan keputusan Presiden. Sebagaimana komisi independen lain yang dihadapkan dengan berbagai reaksi dan ekspektasi, kinerja KPPU patut dicermati karena merupakan elemen penting dalam proses penegakan hukum.

Pasal 35 dan Pasal 36 Undang-Undang Nomor 5 Tahun 1999, memberikan KPPU tugas dan wewenang untuk melakukan penyidikan, penuntutan dan sekaligus sebagai pengadilan yang dapat memutuskan dan menetapkan ada atau tidaknya kerugian baik itu di pihak pelaku usaha lain atau masyarakat. Kekurangan yang sangat nyata, yakni dalam hal pengaturan hukum acaranya walaupun dalam teknis substansial sudah cukup mendapat penjelasan. Sehingga untuk mengetahui proses pemeriksaan oleh KPPU, proses pemeriksaan upaya hukum keberatan di Pengadilan dan proses pemeriksaan upaya hukum Kasasi di Mahkamah Agung tidak dapat ditemukan dalam Undang-Undang tersebut. Di dalam Undang-Undang Nomor 5 Tahun 1999 hanya disebutkan bahwa keberatan diajukan ke Pengadilan Negeri, sedangkan bagaimana cara pemeriksaannya tidak dijelaskan. Sehingga dalam prakteknya cukup menjadi hambatan bagi Pengadilan Negeri dalam melakukan pemeriksaan terhadap upaya hukum keberatan yang dilakukan oleh pihak pelaku usaha yang tidak menerima 
putusan KPPU. Kemudian dikeluarkan Perma Nomor 3 Tahun 2005 untuk mengisi kekosongan hukum acara dalam Undang-Undang No.5 Tahun 1999.

Perlu dilakukan revisi terhadap Undang-Undang Nomor 5 Tahun 1999 mengingat KPPU memiliki kewenangan yang cukup luas diperlukan ketentuan hukum acara yang sangat lengkap, sehingga dalam revisi tersebut perlu melibatkan praktisi dan penegak hukum untuk memperoleh suatu aturan lengkap dan akurat terkait hukum acara agar proses peradilan di KPPU juga dapat berjalan sesuai dengan yang diharapkan. KPPU memiliki kewenangan yang luas di mana kewenangan-kewenangan yang luas tersebut tetap ada batasnya, yaitu dari segi eksekusi putusan, walaupun KPPU bisa memeriksa, menyidik, memanggil para pihak, bahkan membuat suatu putusan terhadap perkara yang diperiksanya tetap saja KPPU tidak bisa melaksanakan eksekusi terhadap putusan yang telah dibuatnya karena untuk melaksanakan eksekusi diperlukan fiat eksekusi pengadilan. Dari segi pidana, walaupun KPPU memiliki kewenangan yang luas untuk melakukan pemeriksaan, tetapi hasil pemeriksaan KPPU tersebut hanya menjadi bukti permulaan yang cukup bagi penyidik.

\section{Penutup}

Monopoli dan persaingan usaha merupakan hal biasa dalam kegiatan ekonomi. Sejauh kegiatan itu dilakukan dalam rambu-rambu hukum, implikasi penerapan monopoli dan persaingan usaha tidak bisa dihindari dalam mekanisme ekonomi pasar. Hanya bedanya apa yang terjadi sebelum adanya Undang-Undang No.5 Tahun 1999 praktek-praktek monopoli maupun persaingan tidak diatur dalam koridor hukum yang seharusnya. Sesudah Undang-Undang No. 5 Tahun 1999 Praktek Monopoli dalam kegiatan bisnis dilarang jika terbukti merugikan pelaku usaha lain, konsumen, masyarakat, maupun negara. Undang-Undang No. 5 Tahun 1999 menegaskan larangan praktek monopoli dan persaingan usaha tidak sehat di antara para pelaku usaha dapat diancam dengan sanksi administratif dan sanksi pidana. Implikasi pemberlakuan undang-undang ini adalah dalam rangka mengantisipasi pasar bebas pada era globalisasi ekonomi guna mewujudkan kemakmuran dan kesejahteraan rakyat sebagaimana diamanatkan UUD 1945. Ketentuan Undang-Udang No. 5 Tahun 1999 telah memenuhi prinsip Undang-Undang Anti Monopoli dalam mengatur Struktur Pasar dan perilaku bisnis, karena memuat gabungan dua pengaturan yang dimasukan dalam satu kitab perundang-undangan baik itu mengenai Undang-Undang Anti Monopoli maupun peraturan perundangan yang menyangkut persaingan usaha atau Competition Act. Sehingga monopoli maupun persaingan usaha dapat berjalan seiring dalam peraturan bisnis di Indonesia. 
Politik hukum persaingan usaha di masa yang akan datang tetap sejalan dengan isi Pasal 33 UUD 1945 (amandemen IV), Rencana Pembangunan Jangka Panjang Tahun 2005-2025 yang dituangkan dalam Undang-UndangNo. 17 Tahun 2007.

Penegakan hukum persaingan usaha di Indonesia diserahkan kepada Komisi Pengawas Persaingan Usaha (KPPU), selain keterlibatan aparat Kepolisian, Kejaksaan, dan Pengadilan. Penegakan pelanggaran hukum persaingan harus dilakukan terlebih dahulu melalui KPPU.

\section{Daftar Pustaka}

\section{A. Buku}

Areeda, Philip, 1992. Antitrust Law As Industrial Policy, Berlin: Oxford University.

Friedman, W, 1960. Legal Theory, London, Steven \& Sons Limited.

Hartono, C,F,G, Sunaryati, 1991, Politik Hukum Menuju Satu Sistem Hukum Nasional, Bandung: Alumni.

Ibrahim, Johnny, 2006. Hukum Persaingan Usaha: Filsafat, Teori, Dan Implikasi Penerapannya Di Indonesia, Malang: Bayumedia.

Institute (Center For Democracy, Nationalisme, And Market Economy Studies)-KPG, 2004.

Kantz, Michael Dan Rosen, Harveey S, 1994, "Microeconomic", USA : Richard D Irwin Inc.

Loughlin, Colleen, 1999. Et Al, "Laporan Kebijakan Persaingan Indonesia," ELIPS, Kerja sama Antara USAID Dengan Pemerintah Indonesia.

M,D, Moh. Mahfud, 2009. Politik Hukum Di Indonesia, Jakarta: Rajagrafindo Persada.

Mallarangeng, Rizal, 1991. Mendobrak Sentralisme Ekonomi: Indonesia 1986-1992, Cetakan Kedua, Jakarta: Freedom Satjipto Rahardjo, Ilmu Hukum, Cet III, Bandung: Citra Aditya Bakti.

Maulana, Agus, 2000. Pengantar Mikro Ekonomi, Jilid II, Jakarta: Bina Rupa Aksara.

Prayoga, Ayudha D., Et Al (Ed), 2000. Persaingan Usaha Dan Hukum Yang Mengaturnya Di Indonesia, Jakarta: Proyek ELIPS.

R, Gregory Paul And Stuart, Robert C., 1992. Comparative Economic System, Boston: Houghton Miffin Company.

Rasjidi, Lili, 1996. Dasar - Dasar Filsafat Hukum, Bandung: Citra Aditya Bakti.

Ros, Ginting Elyta, 2001, Hukum Anti Monopoli, Bandung: PT Citra Aditya Bakti. 
Sjahdeini, Sutan Remy, 2000. "Larangan Praktek Monopoli Dan Persaingan Usaha Tidak Sehat" Jurnal Hukum Bisnis Volume 10, Jakarta: Yayasan Pengembangan Hukum Bisnis.

Suherman, Ade Maman, 2001. Aspek Hukum Dalam Eknomi Global, Jakarta: Ghalia Indonesia.

Wahjono, Padmo, 1986. Indonesia Negara Berdasarkan Atas Hukum, Cet II, Jakarta: Ghalia Indonesia.

Yani, Ahmad Dan Gunawan, Widjaja, 2006. Anti Monopoli, Jakarta: Rajawali Pers.

\section{B. Jurnal}

Maarif, Syamsul, Tantangan Penegakan Hukum Persaingan Usaha Di Indonesia,: Jurnal Hukum Bisnis, Yayasan Pengembangan Hukum Bisnis, Vol, 19, Mei-Juni 2002.

Posner, Richard A, 1998,Creating A Legal Framework For Economic Development", The World Bank Research Observer, Vol, 13, No, 1 February 1998.

Muladi, "Menyongsong Keberadaan UU Persaingan Sehat Di Indonesia", Dalam UU Anti monopoli Seperti Apakah Yang Sesungguhnya Kita Butuhkan?Newsletter Nomor 34 Tahun IX, Yayasan Pusat Pengkajian Hukum, Jakarta.

Radhie, Teuku Mohammad, 2009, Pembaruan Dan Politik Hukum Dalam Rangka Pembangunan Nasional, Prisma No, 6 Tahun II, Desember 1973,

\section{Peraturan Perundang-undangan}

Undang-Undang Dasar 1945

Undang-Undang Nomor 5 Tahun 1999 tentang Larangan Praktek Monopoli Dan Persaingan Usaha Tidak Sehat

Undang-Undang RI Nomor 17 Tahun2007 tentang Rencana Pembangunan Jangka Panjang Nasional Tahun 2005-2025 Bab IV Arah Tahapan, Dan Prioritas Pembangunan Jangka Panjang Tahun 2005-2025.

\section{Internet}

Didin S. Damanhuri, SDM Indonesia Dalam Persaingan Global, At Http://Www.Sinarharapan.Co.Id/Berita/0306/13/Opi01.Html.

Https://Balianzahab.Wordpress.Com/Makalah-Hukum/Politik-Hukum/ApaPolitik-Hukum-Itu/ 